\title{
The Transfer Characteristics of Hair Cells Encoding Mechanical Stimuli in the Lateral Line of Zebrafish
}

\author{
Paul Pichler and Leon Lagnado \\ School of Life Sciences, University of Sussex, Brighton BN1 9QG, United Kingdom
}

Hair cells transmit mechanical information by converting deflection of the hair bundle into synaptic release of glutamate. We have investigated this process in the lateral line of larval zebrafish (male and female) to understand how stimuli are encoded within a neuromast. Using multiphoton microscopy in vivo, we imaged synaptic release of glutamate using the reporter iGluSnFR as well as deflections of the cupula. We found that the neuromast is composed of a functionally diverse population of hair cells. Half the hair cells signaled cupula motion in both directions from rest, either by increasing glutamate release in response to a deflection in the positive direction or by reducing release in the negative direction. The relationship between cupula deflection and glutamate release demonstrated maximum sensitivity at displacements of just $\sim 40 \mathrm{~nm}$ in the positive direction. The remaining hair cells only signaled motion in one direction and were less sensitive, extending the operating range of the neuromast beyond $1 \mu \mathrm{m}$. Adaptation of the synaptic output was also heterogeneous, with some hair cells generating sustained glutamate release in response to a steady deflection of the cupula and others generating transient outputs. Finally, a distinct signal encoded a return of the cupula to rest: a large and transient burst of glutamate release from hair cells unresponsive to the initial stimulus. A population of hair cells with these different sensitivities, operating ranges, and adaptive properties will allow the neuromast to encode weak stimuli while maintaining the dynamic range to signal the amplitude and duration of stronger deflections.

Key words: lateral line; mechanosensation; neuromast; ribbon synapse; zebrafish

\section{Significance Statement}

Hair cells transmit information about mechanical stimuli by converting very small deflections of their hair bundle into changes in the release of the neurotransmitter glutamate. We have measured this input/output relation in the live fish using a fluorescent protein and find that different hair cells vary in their mechanical sensitivity and the time course of their response. These variations will allow the fish to sense the timing and duration of both very weak stimuli ( $\sim 40 \mathrm{~nm}$ deflections) and strong stimuli $(\sim 1 \mu \mathrm{m})$, underlying the ability of the fish to avoid predators and maintain its body position in flowing water.

\section{Introduction}

An increasingly important context for the study of mechanotransduction is the lateral line of zebrafish, which is used to detect vibrations and pressure gradients in the hydrodynamic environment (Chou et al., 2017; Erickson et al., 2017; Graydon et al., 2017; Maeda et al., 2017; Oteiza et al., 2017; Sheets et al., 2017).

\footnotetext{
Received June 11, 2018; revised 0ct. 9, 2018; accepted 0ct. 12, 2018.

Author contributions: P.P. wrote the first draft of the paper; L.L. edited the paper.P.P. and L.L. designed research; P.P. performed research; P.P. and L.L. analyzed data; P.P. and L.L. wrote the paper.

This work was supported by the Wellcome Trust Grant 102905/Z/13/Z. We thank all members of the laboratory for their input during this project and to Guy Richardson for his helpful advice.

The authors declare no competing financial interests.

Correspondence should be addressed to Leon Lagnado, School of Life Sciences, University of Sussex, Brighton BN1 90G, UK. E-mail: I.lagnado@sussex.ac.uk.

https://doi.org/10.1523/JNEUROSCl.1472-18.2018 Copyright $\odot 2019$ Pichler and Lagnado

This is an open-access article distributed under the terms of the Creative Commons Attribution License Creative Commons Attribution 4.0 International, which permits unrestricted use, distribution and reproduction in any medium provided that the original work is properly attributed.
}

This sensory system drives behaviors such as predator avoidance and rheotaxis- the maintenance of body position against a current (McHenry et al., 2009; Stewart et al., 2013; Olive et al., 2016). Rheotaxis operates in larval zebrafish in the absence of visual input using an algorithm that depends on the detection of flow velocity gradients on either side of the body (Oteiza et al., 2017). To understand the generation of these behaviors we therefore need to characterize how hair cells within the lateral line transfer information about mechanical stimuli.

The sense organs detecting changes in hydrodynamic pressure, the neuromasts, are distributed over the head and body, each being composed of 10-20 hair cells that project into a single cupula and therefore act as a population to signal the mechanical stimulus at that part on the body (Pujol-Martí and López-Schier, 2013). This signal is encoded as changes in the rate of glutamate release from ribbon-type synapses similar to those found in hair cells of the auditory system (Nicolson, 2015). Deflections of the cupula are encoded by a "push-pull" system in which half the hair 
cells are depolarized by motion in one direction and the other half by motion in the opposite direction, with segregation of these two populations onto separate afferent fibers (Faucherre et al., 2009).

Measuring the transfer characteristics of hair cells in terms of the final synaptic output is essential to understanding how mechanical information is transmitted to afferent neurons. However, a number of fundamental questions about signaling in the lateral line remain unanswered. How does glutamate release from individual hair cells encode deflections of the cupula? What is the dynamic range over which signaling occurs? And how does the output from the synaptic ribbon adapt? It is equally important to understand how these properties might vary between hair cells to determine how the population as a whole acts to encode the amplitude and duration of a stimulus.

Measuring the input-output relation of a neuromast requires assaying the release of glutamate from individual hair cells in response to measured deflections of the hair bundle. The output of hair cells has been studied by measuring capacitance changes (Beutner et al., 2001; Brandt et al., 2005; Ricci et al., 2013; Olt et al., 2014) or by recording synaptic currents in the afferent fiber (Keen and Hudspeth, 2006; Li et al., 2009; Weisz et al., 2012), but both these techniques have the disadvantage that they require the synapse to be activated by direct injection of current, bypassing the normal process of mechanotransduction. More recently, an optical approach has been used to monitor hair cell output, based on the reporter sypHy (Zhang et al., 2018). A significant drawback of sypHy, however, is that the signal it generates reflects a balance between exocytosis and endocytosis, requiring careful corrections to separate the two processes (Granseth et al., 2006; Odermatt et al., 2012). We therefore turned to the fluorescent glutamate sensor iGluSnFR (Marvin et al., 2013), which provides a more direct measure of glutamate concentrations around synaptic sites. Coupled with fluorescence measurements of cupula position, this allowed an all-optical approach to investigating the transfer characteristics of both individual hair cells and the population operating within a single neuromast.

Here we show that the output of a neuromast is determined by a heterogeneous population of hair cells that vary in mechanical sensitivity and the dynamics of adaptation, generating a population code that signals weak stimuli while maintaining the ability to encode the amplitude and duration of stronger deflections.

\section{Materials and Methods}

Fish husbandry. Adult zebrafish (Danio rerio) were maintained in fish water at $28.5^{\circ} \mathrm{C}$ under a $14 / 10 \mathrm{~h}$ light/dark cycle under standard conditions (Brand et al., 2002). Fish were bred naturally and fertilized eggs were collected, washed with distilled water and transferred into $50 \mathrm{ml}$ of E2 medium (concentrations in mM: $0.05 \mathrm{Na}_{2} \mathrm{HPO}_{4}, 1 \mathrm{MgSO}_{4} 7 \mathrm{H}_{2} \mathrm{O}, 0.15$ $\left.\mathrm{KH} 2 \mathrm{PO}_{4}, 0.5 \mathrm{KCl}, 15 \mathrm{NaCl}, 1 \mathrm{CaCl}_{2}, 0.7 \mathrm{NaHCO}_{3}, \mathrm{pH} 7-7.5\right)$. At $24 \mathrm{~h}$ postfertilization 1-phenyl2-thiourea was added to yield a final concentration of $0.2 \mathrm{~mm}$ to inhibit pigment formation. All procedures were in accordance with the UK Animal Act, 1986 and were approved by the Home Office and the University of Sussex Ethical Review Committee.

Fish lines. The Tg[HuC::GCaMP6f] line (kindly provided by Isaac Bianco, University College London) expresses GCaMP6f pan-neuronally, including in afferent neurons of the lateral line, but not in hair cells. The $\operatorname{Tg}[$ Sill2, UAS::iGluSnFR] line expresses iGluSnFR (Marvin et al., 2013) exclusively in afferent neurons of the lateral line system (Pujol-Martí et al., 2012). It was generated by injecting the Sill2 construct, containing the Sill enhancer driving expression of the Gal4-VP16 element (kindly provided by Hernan Lopez-Schier, Helmholtz Zebtrum München, German Research Center for Environmental Health), into single-cell stage embryos expressing 10xUAS::iGluSnFR. Larvae were sorted for expression of iGluSnFR and reared to adulthood to identify fish with germ-line transmission (founders). To generate the Tg[Sill2, UAS::iGluSnFR, Rib::
Rib-mCherry], the Sill construct was injected into the embryos derived from an outcross between 10xUAS::iGluSnFR and Rib::Rib-mCherry (Odermatt et al., 2012) adults and screened for the expression of iGluS$\mathrm{nFR}$ and mCherry. This line allowed us to image the iGluSnFR signal in afferent neurons while visualizing synaptic ribbons in hair cells. All fish were maintained in a nacre mutant background (Lister et al., 1999).

Properties of the iGluSnFR sensor. We used the iGluSnFR variant developed by Marvin et al. (2013), which is maximally excited at $\sim 930 \mathrm{~nm}$ in the two-photon regime and has a dynamic range of $\Delta F / F=4.5$. This variant responds rapidly to synaptic release of glutamate: transients generated by one vesicle reach a peak within $\sim 10 \mathrm{~ms}$ and then decay with a time constant of 30-50 ms, as measured in hippocampal cultures (Marvin et al., 2013) and in vivo at ribbon synapses in the retina of larval zebrafish (Lagnado et al., 2018). The response of iGluSnFR also appears linear over a wide range: in retinal ganglion cells, the change in iGluSnFR fluorescence is directly proportional to the glutamate activated current across at least a 20 -fold range of visually evoked responses (Borghuis et al., 2013). These properties indicate that the detection of fast changes in synaptic glutamate concentration was limited by the sampling frequency of the experiments rather than the off-rate of the reporter. In a typical experiment imaging at $10-50 \mathrm{~Hz}$ we were able to resolve the decline in the iGluSnFR signal at the end of a large step displacement (recovery to baseline within $\sim 250-400 \mathrm{~ms}$; Fig. $1 F$ ), as well as the time constants of adaptation (averaging $600 \mathrm{~ms}$; Fig. 7).

Mounting and cupula staining. All experiments were performed at room temperature $\left(20-25^{\circ} \mathrm{C}\right)$ using larvae at $7-10 \mathrm{~d}$ postfertilization (dpf). At $4 \mathrm{dpf}$, embryos were screened for the strongest expression of the respective transgene. Larvae were anesthetized by immersion in $0.016 \%$ tricaine (MS-222), diluted in E2. They were then placed side-down into a "fish-shaped" pit carved into a thin $(\sim 1 \mathrm{~mm})$ layer of PDMS (Sylgard184, Dow Crowning) on a coverslip. Mechanical stability was provided by a 'harp' (Warner Instruments) placed on top of the larva. The pressure applied by the nylon strings was adjusted to allow normal blood flow while maintaining enough pressure to hold down the larva. The larva was then paralyzed by injection of $0.25 \mathrm{~mm} \alpha$-Bungarotoxin (Tocris Bioscience) into the heart. To avoid damaging the cupula, special care was taken not to touch the upward-facing side of the fish during the mounting procedure. The cupula was then stained by incubating the fish in a 1:500 dilution of $1 \mathrm{mg} / \mathrm{ml}$ WGA AlexaFluor-594 or WGA AlexaFluor-350 (Life Technologies) for $2 \mathrm{~min}$ followed by thorough washing with E2. This staining was not always evenly distributed across the surface of the cupula (Fig. $2 A, C$ ). When counter-staining hair cells with FM4-64 (Synaptored, Biotium) larvae were incubated in a $1 \mu \mathrm{M}$ solution for $1 \mathrm{~min}$ and then washed with E2.

Two-photon imaging. Fish of either sex were imaged on a custom built two-photon microscope driven by a mode-locked Titanium-sapphire laser (Chameleon 2, Coherent) tuned to $915 \mathrm{~nm}$ (Odermatt et al., 2012). Excitation was delivered through a $40 \times$ water-immersion objective (Olympus, 40× LUMIPlanF, NA: 0.8) and emitted photons were collected both through the objective and an oil condenser (NA 1.4, Olympus) below the sample. Visible emission was separated from IR light by a dichroic mirror (760dcxru) above the objective and focused onto a GaAsP photodetectors (H10770PA-40, Hamamatsu). A filter slider in front of the detector was used to switch between green $(525 / 70 \mathrm{~nm})$ and red $(620 / 60 \mathrm{~nm})$ emission filters. A second detector below the condenser only collected green emission through a 530/60 nm filter. Dual color stacks of Tg[Sill2, UAS::iGluSnFR, Rib::Rib-mCherry] were acquired by simultaneously exciting the iGluSnFR and mCherry at $1030 \mathrm{~nm}$ and collecting the emitted photons through the objective (red 620/60 nm emission filter) and condenser (green 530/60 nm emission filter), respectively. Photocurrents generated by the detectors were passed through a transimpedance amplifier (Model SR570, Stanford Research Systems) and low-pass filtered $(300 \mathrm{kHz})$. When only the iGluSnFR signal was to be recorded, the currents from both photodetectors were summed before the amplification step to increase the signal-to-noise ratio. The microscope was controlled by ScanImage v3.8 (Vidrio Technologies) and image acquisition was synchronized with the stimulus. Image sequences were acquired at $10-50 \mathrm{~Hz}$. 
A
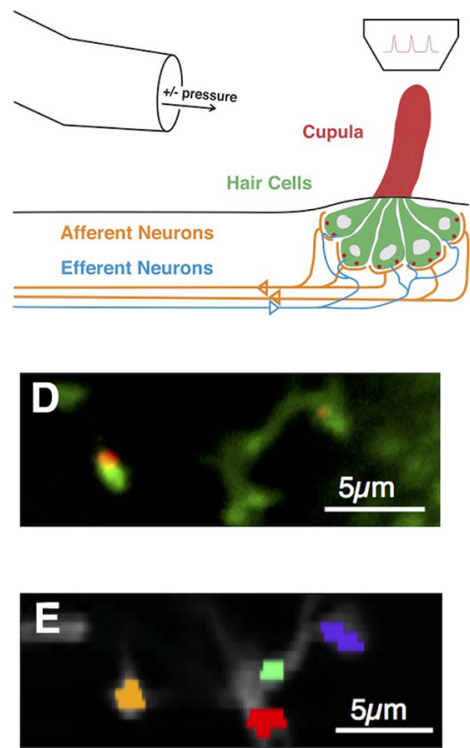

G

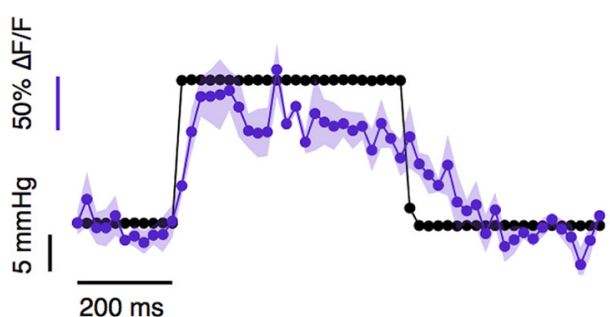

$\mathbf{F}$
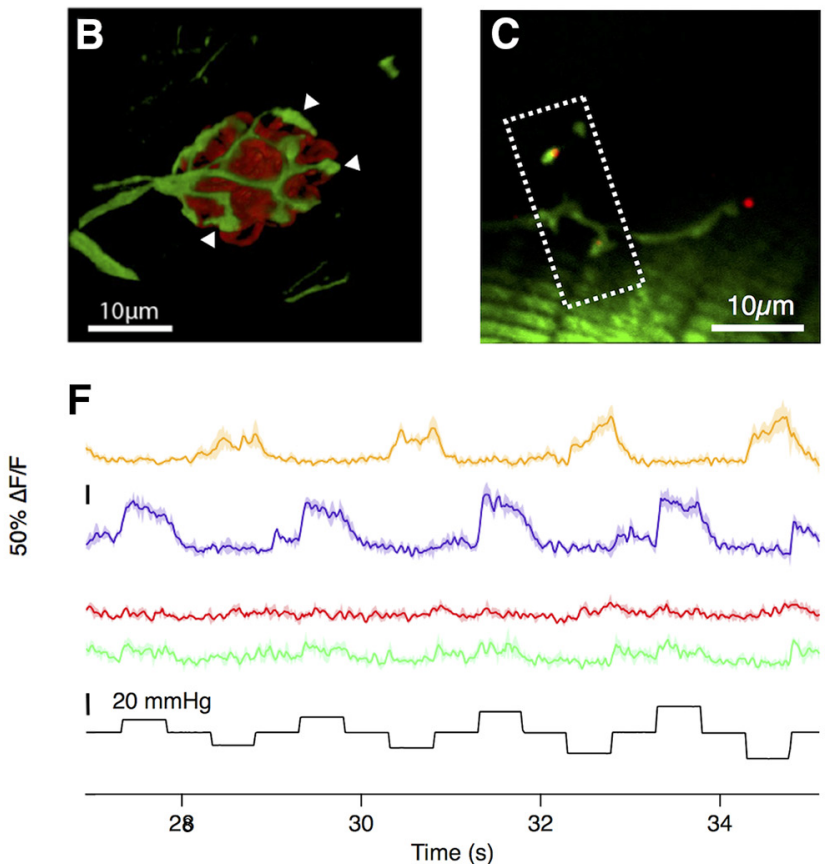

H

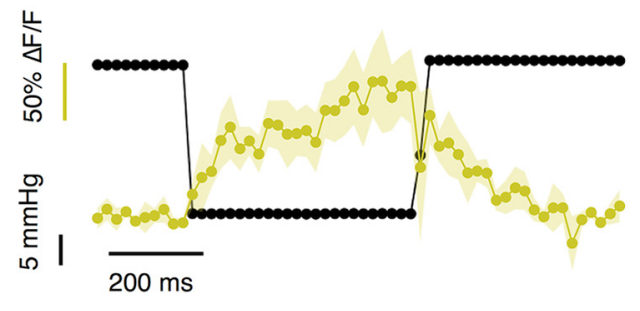

Figure 1. Imaging glutamate release of lateral line hair cells in vivo. A, Neuromasts, consisting of 15-20 mechanosensory hair cells are distributed across the surface of zebrafish larvae. Upon deflection of the cupula, hair cells transmit the mechanical signal by releasing glutamate onto afferent neurons, which project into the hindbrain of the larva. Experimentally, the cupula of a neuromast of the posterior lateral line (L3-L6) was stimulated with positive and negative pressure steps applied through a bent pipette along the anterior-posterior direction of the larva. The glutamate released by hair cells was imaged through a two-photon microscope. $\boldsymbol{B}$, The fluorescent glutamate reporter iGluSnFR was expressed over the surface of afferent neurons (green), which form a basket-like structure around hair cells, here counterstained in red using FM4-64. White arrowheads indicate such postsynaptic varicosities. C, Image of a neuromast in a larva at $7 \mathrm{dpf}[$ Tg(Sill2, UAS::iGluSnFR, Rib::Rib-mCherry)] showing varicosities of one afferent neuron (green) as well as synaptic ribbons at the basal side of hair cells (red). D, Close-up of the boxed area in C. Of the four visible varicosities, two did not coincide with presynaptic ribbons. $\boldsymbol{E}$, ROls used for analysis. $\boldsymbol{F}$, The responses of the four ROls in $\boldsymbol{E}$. The amber and purple ROls, postsynaptic to ribbons, responded to positive and negative pressure steps, respectively. The red and green ROls not opposed to ribbons did not respond. (Shaded area indicates SEM of 3 repeats.) $\boldsymbol{G}, \boldsymbol{H}, \mathbf{M a g n i f i c a t i o n ~ o f ~ t h e ~ r e s p o n s e s ~ t o ~}$ a single positive and negative pressure step of the purple and amber ROls, respectively. Markers are $20 \mathrm{~ms}$ apart (image sequence was acquired at $50 \mathrm{~Hz}$ ) and an initial peak of the response is reached within $100-150 \mathrm{~ms}$.

Mechanical stimulation. Pressure steps were applied to a neuromast through a glass pipette attached to a high speed pressure clamp (HSPC-1, ALA Scientific; Trapani et al., 2009). The output pressure (as measured at the back of the pipette) was controlled using mafPC software (courtesy of M. A. Xu-Friedman, University of Buffalo) running in IgorPro (WaveMetrics) and synchronized to image acquisition. (The applied pressure as measured at the end of the pipette was recorded as a separate channel in ScanImage.) The micropipette was pulled to a diameter of $\sim 30 \mu \mathrm{m}$ and the tip bent through $30^{\circ}$ using a micro forge (Narishige) to allow liquid flow parallel to the body of the larva. The tip was positioned $\sim 20 \mu \mathrm{m}$ above the body, $\sim 100 \mu \mathrm{m}$ from the neuromast. Before approaching the neuromast the pressure clamp offset was set so that the sensor monitoring the pressure at the back of the pipette was at zero and produced no net flow. This study was confined to neuromasts of the posterior lateral line (L3-L6) with an "anterior-posterior" axis of sensitivity. The direction of the pipette (pointing toward the tail or toward the head) was changed during the course of some experiments but did not affect measurements.

Measuring deflections of the cupula. The angular deflection of the stained cupula was assessed by measuring its translational displacement in multiphoton images in planes at different $z$ distances from the surface of the hair cells. The measurements were made at a variety of stimulus pressures and repeated in 3-4 planes in $5 \mu \mathrm{m}$ increments. The central position of the cupula within each frame was extracted by first thresholding the image and then fitting an ellipse to estimate the center of mass. Next, the translational deflections induced by the applied pressure steps in each plane were calculated: these were consistent with the proximal regions of the cupula $(z<15-20 \mu \mathrm{m})$ behaving as a pivoting beam (McHenry and van Netten, 2007). The angular deflection was then calculated as $\tan ^{-1}(\Delta x / z)$, where $\Delta x$ was the translation within the plane and $z$ the height above the surface of the hair cell. This angle was calculated in each of the planes and subsequently averaged. In this way, a calibration of the angular deflection of the cupula for each stimulus pressure was obtained for each experiment. This relationship was linear, and the slope is indicated by the degree/millimeter mercury calibration in the respective figure legends. This calibration was repeated if, for instance, the pipette was moved.

The pressure steps used to stimulate the cupula were filtered by the mechanical properties of the pressure clamp, the hydrodynamics of the fluid and the mechanical properties of the cupula itself. Under the experimental conditions mentioned above (pipette diameter of $\sim 30 \mu \mathrm{m}$, $\sim 100 \mu \mathrm{m}$ away from the cupula) and for weak to intermediate pressure steps, this meant that the cupula usually reached its "final" deflection 
A

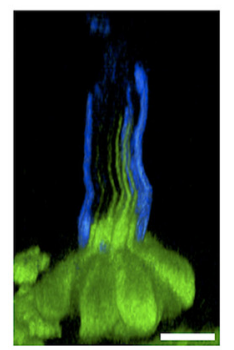

B

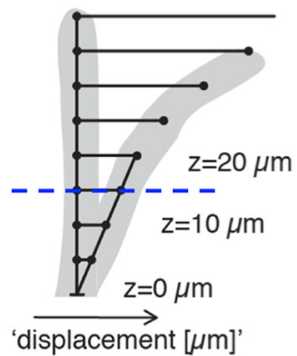

C

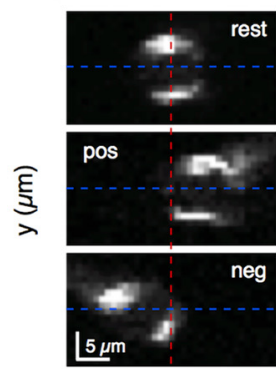

$x(\mu \mathrm{m})$
D

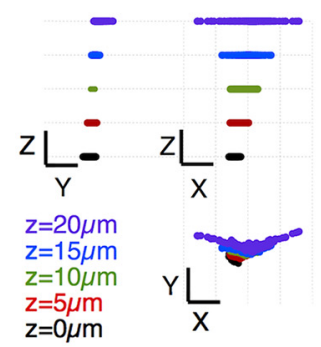

E

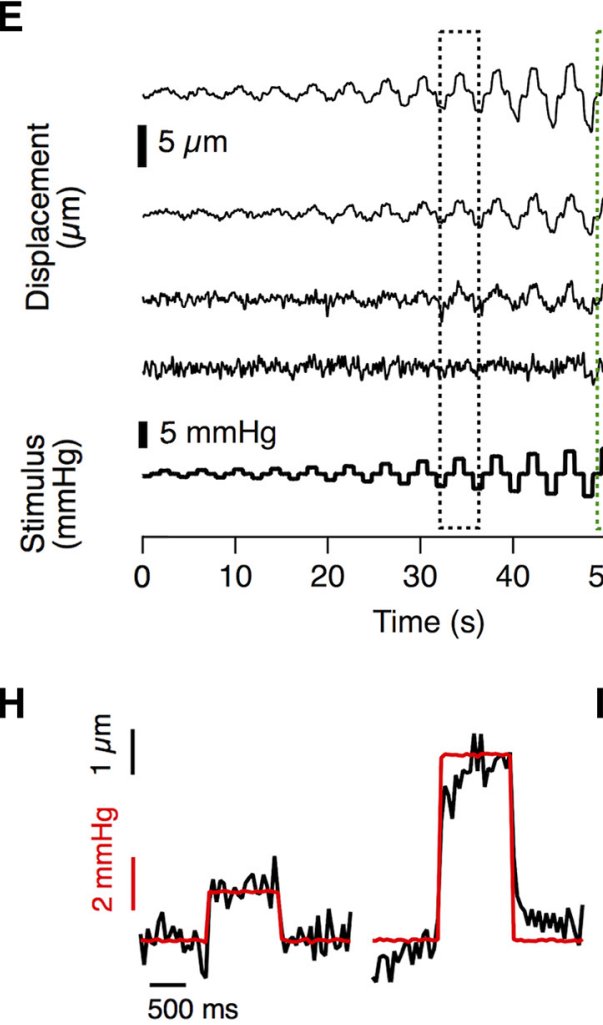

$\mathbf{F}$

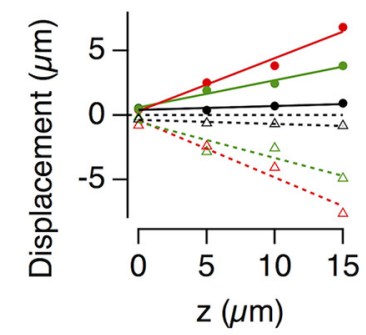

G

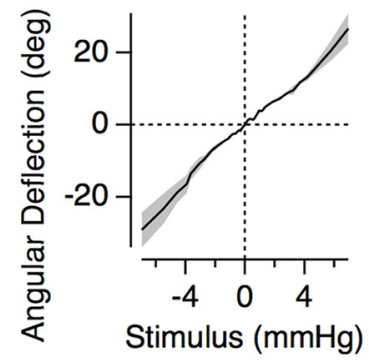

Figure 2. Optically assessing cupula deflection-the mechanical input of lateral line hair cells. $A$, Side projection of a neuromast expressing GFP in hair cells with the surface of the cupula stained with AlexaFluro-350-WGA. Notice how the kinocilia extend approximately half way up the cupula. The staining was not evenly distributed across the surface of the cupula. Scale bar, $10 \boldsymbol{\mu m}$. $\boldsymbol{B}$, Schematic of the model used to calculate angular deflections of the cupula from a pivot at its base. The translational deflection for a given stimulus pressure was measured at several distances $z$ above the apical surface of the hair cell. $\boldsymbol{C}$, Three representative frames of the stained cupula at $z=15 \mu \mathrm{m}$ ( $\boldsymbol{B}$, blue dashed line) at rest and deflected by a positive (pos) and negative (neg) pressure step. The angular deflection was calculated as $\tan ^{-1}(\Delta x / z)$, where $\Delta x$ was the translation in the center of mass of the staining from the rest position (dashed red line indicated center position). $D$, Cupula motion in space over the course of the entire experiment can be extracted from these data. Stimulation along the $x$-axis (parallel to the fish), led to increasingly strong translational displacements toward the tip of the cupula along the $x$-axis and hardly induced motion along the orthogonal, $y$-axis. Scale bars: $x, y, 10 \mu \mathrm{m} ; z, 5 \mu \mathrm{m}$. $\boldsymbol{E}$, Traces showing $x$ displacement as a function of time at four different $z$ distances and for a variety of pressure steps (bottom trace). The image sequences were obtained at $20 \mathrm{~Hz}$. $\boldsymbol{F}$, The $x$ displacements to positive and negative pressure steps of increasing magnitude (black, green, and red, corresponding to stimuli delivered in boxes shown in $\boldsymbol{E}$ ). Note that $x$ displacement is directly proportional to $z$ at any pressure, indicating that the proximal part of the cupula indeed acts as a beam, deflecting at a pivot point at its base. Several measurements within this rigid region of the cupula could therefore be averaged. $\mathbf{G}$, Example of a calibration curve relating the stimulus pressure to the angular deflection (average of several $\Delta x$ measurements in the "rigid" part of the cupula), gray shading indicated SEM, see Materials and Methods. These relations were generally linear. $\boldsymbol{H}$, Translational displacement (same as in $\boldsymbol{F}$ ) of the cupula at $z=10 \mu \mathrm{m}$ for an intermediate (left) and strong (right) deflection step. Although the intermediate pressure step led to a deflection within 1 sample point $(50 \mathrm{~ms})$, an additional slow small creep was apparent in some of the stronger steps. $I$, Two examples of translational displacements of cupulae at $z=10 \mu \mathrm{m}$ to saturating pressure steps in which the applied pressure led to a steady deflection within 1 sample point ( 50 ms, indicated by markers).

within $50 \mathrm{~ms}$ after stimulus onset (one sample point in Fig. $2 \mathrm{H}$, left, $I$ ). For stronger stimuli, the initial, fast deflection was sometimes followed by a slow creep (Fig. $2 H$, right).

Imaging protocol. After the larva was placed under the two-photon microscope an afferent neuron expressing iGluSnFR and innervating an appropriate neuromast (L3-L6) was identified. Subsequently the stimulating pipette, connected to the zeroed HSPC1 was manually approached while monitoring the cupula position through the eyepieces of the microscope to ensure that the resting pressure of the pressure clamp did not alter the cupula's resting position. After the pipette was positioned, a high-resolution 3D image stack was taken for later reference [a dual color stack in the case of the $\operatorname{Tg}($ Sill2, UAS::iGluSnFR, Rib::Rib-mCherry)]. The focal plane was chosen to capture a good number of varicosities in labeled afferent neurons, indicating the positions of hair cell synapses. We imaged an average of 5.1 active varicosities per neuromast.

The dynamic range of the set of varicosities within the focal plane was initially assessed coarsely using a stimulus protocol consisting of three positive and three negative pressure steps of varying amplitude. After 
that, a longer stimulus protocol was applied involving smaller increments in pressure (usually 15-20 positive and negative) allowing a more detailed construction of the mechanical tuning curve. To allow averaging, this protocol was repeated three times with $\sim 20-30$ s breaks in between. If the response of a synapse declined significantly during these three repeats it was discarded from the analysis. Such changes could occur through photobleaching of the iGluSnFR protein reducing the SNR, the pipette being clogged by debris or drifting motion of the preparation. After delivery of stimulus protocols and imaging of iGluSnFR responses, the pressure-deflection relationship was established by using a protocol consisting of the same positive and negative pressure steps (described above).

Image analysis and statistics. Images were analyzed in Igor Pro (Wavemetrics) using custom-written software including the SARFIA toolbox (Dorostkar et al., 2010). Image sequences containing small drifts in the $x-y$ dimension were registered but those with large drifts, including potential $z$-motions, were discarded. Regions-of-interest (ROIs) were determined using an algorithm that began by identifying pixels with both large signals and high degrees of temporal correlation. Pixels surrounding thee ROI "seeds" were added to the ROI until the correlation value fell below a threshold. Background fluorescence was subtracted by manually choosing a region within the image sequences that did not contain a stimulus-dependent signal and subtracting the average in that background ROI from the average in the varicosity ROI on a frame by frame basis. Baseline fluorescence $(F)$ was defined as the average fluorescence preceding the first stimulation interval. The change in fluorescence relative to baseline $(\Delta F / F)$ was calculated and used for further analysis. Every response constitutes the average of the three stimulus repetitions.

The population data in Figure 4 were generated as follows: for each ROI, signals were measured for a wide range of cupula deflections, yielding $\sim 2800$ paired measurements of $\Delta F / F$ and cupula deflection, from 67 hair cells in 13 fish. The measurements were accumulated by sorting these signals according to the deflection absolute angle of the cupula (pooled positive and negative deflections), binning them and then averaging responses within the bin.

The adaptation index (AI) was calculated as follows:

$$
\mathrm{AI}=\left(\mathrm{R}_{\text {peak }}-\mathrm{R}_{\text {sustained }}\right) / \mathrm{R}_{\text {peak }} \text {. }
$$

Where $R_{\text {peak }}$ is the instantaneous peak response after stimulus onset and $R_{\text {sustained }}$ is the average responses during the last $100 \mathrm{~ms}$ of stimulus presentation. Therefore, an AI close to 0 indicates no adaptation, an AI close to 1 indicates complete adaptation and a negative AI indicates sensitization.

The relative set-point (SPr) was calculated as follows:

$$
\operatorname{SPr}=1-\operatorname{abs}\left\{\mathrm{R}_{\min } / \mathrm{R}_{\max }\right\},
$$

where $R_{\max }$ is the saturating response in the preferred direction of deflection and $R_{\min }$ is the maximum change in the opposite direction.

Experimental values in the text and results on graphs are expressed as mean \pm SEM. Errors estimated for parameters fitting functions to results are expressed as $\pm \mathrm{SD}$. Potential correlations between the half-angles, working ranges (WRs), and relative set-points measured within individual neuromasts were investigated using the Spearman rank correlation test.

Leon Lagnado should be contacted for any data or material requests.

\section{Results}

\section{An all-optical approach to measuring the transfer characteristics of hair cell ribbon synapses in vivo}

The lateral line system has been studied intensively but the input/ output relation of hair cells within neuromasts is still unclear. To observe the output in larval zebrafish we used the Sill promoter to drive expression of the fluorescent glutamate sensor iGluSnFR in the surface membrane of primary afferents postsynaptic to hair cell ribbons (Pujol-Martí et al., 2012; Marvin et al., 2013; Fig. $1 A-C)$. Neuromasts in the posterior lateral line were stimulated using a narrow pipette that applied positive and negative pressure steps, generating iGluSnFR signals at distinct hotspots (Fig. 1D$F)$. These hotspots were identified as the outputs of ribbon synapses based on two pieces of evidence. First, the hotspots coincided with varicosities of the afferent fiber, recognizable by their bulged morphology (Fig. 1B, white arrowheads), which have previously been shown to constitute stable afferent synapses onto single hair cells (Faucherre et al., 2009). Second, iGliSnFR hotspots coincided with presynaptic ribbons labeled using Ribeye-mCherry (Odermatt et al., 2012). Figures 1,D and E, home in on four varicosities from two afferents: two of the ROIs were contacted by one ribbon (amber and purple ROIs), whereas the other two were not (red and green ROIs). iGluSnFR signals were only observed in areas that were in close apposition to a ribbon synapse (Fig. $1 F$ ), and this was the rule in all three neuromasts in which this test was made.

To quantify the mechanical input to the hair cells, deflections of the cupula were visualized by staining polysaccharides on the surface blue or red with AlexaFluor-350/594 coupled Wheat Germ Agglutinin (Fig. 2 A, C; detailed in Materials and Methods). The rotational deflection of the cupula was calculated based on the idea that the proximal region acts as a rigid lever pivoting on a plane at the apical surface of the hair cells (Fig. 2B; McHenry and van Netten, 2007). We tested this model by imposing a variety of pressure steps (Fig. 2E, bottom) and tracking the translational motion of the cupula through planes at four different distances from the apical surface of the hair cell. Figure $2 C$ shows images of the cupula at $z=15 \mu \mathrm{m}$, from which the $x$ translation was estimated from the movement of the center of mass of the fluorescence. At any single pressure, the $x$ translations at different $z$ gave consistent estimates of the angle of rotation confirming that the lower part of the cupula behaves as a beam pivoting at its base (Fig. 2D,F). We were therefore able to calibrate the relation between applied pressure and rotation of the cupula for each experiment (Fig. 2G). This calibration was necessary because of variations in experimental factors such as the diameter and angle of the pipette delivering the stimulus, as well as biological factors altering the flexural stiffness of the cupula such as its height and the number of kinocilia embedded within it (McHenry and van Netten, 2007).

The proximal region of the cupula contains the kinocilia and hair bundles of all the hair cells within the neuromast (Fig. 2A), so the angle of the cupula quantifies the sensory input to the neuromast organ as a whole. Crucially, we were able to relate this stimulus to the output from multiple hair cells within a neuromast. For example, Figure $1 F$ demonstrates the simultaneous measurement of activity from synapses of opposite polarity: whereas the purple ROI was activated by positive deflections toward the head, the amber ROI was activated by negative deflections toward the tail.

It is important to consider the temporal relation between the command signal delivered to the device controlling the stimulation pipette, the deflection of the cupula and the iGluSnFR signal recorded. In the majority of experiments the deflection of the cupula reached a steady value within one or two sample points, equivalent to $50-100 \mathrm{~ms}$ (Fig. $2 \mathrm{H}, \mathrm{I}$ ), regardless of applied pressure. In some cases, however, the strongest pressure steps generating saturating iGluSnFR signals also caused a slower creep in cupula deflection (Fig. $2 H$, right), equivalent to $\sim 15 \%$ of the initial displacement. The source of this creep was not clear and in these cases the stimulus applied to the neuromast was quantified as the initial fast deflection.

The iGluSnFR signal indicating an increase in glutamate release appeared slightly delayed relative to cupula deflection, 
A

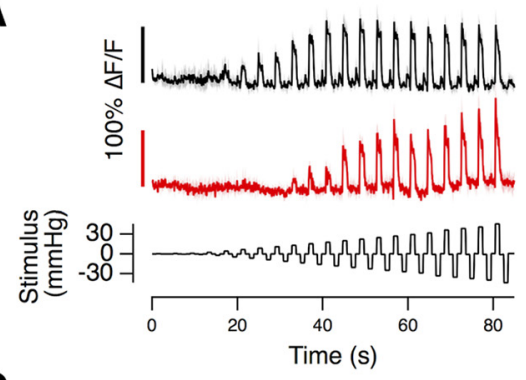

C

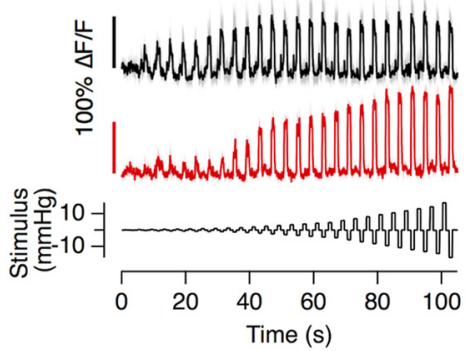

E

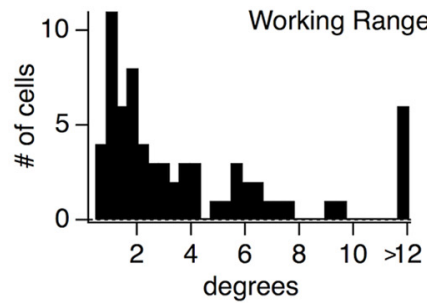

G

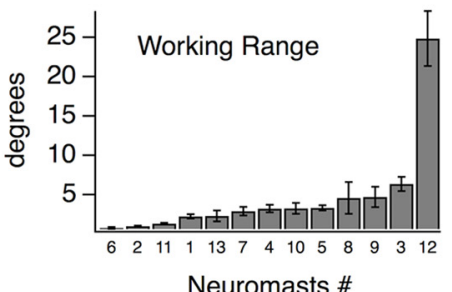

B

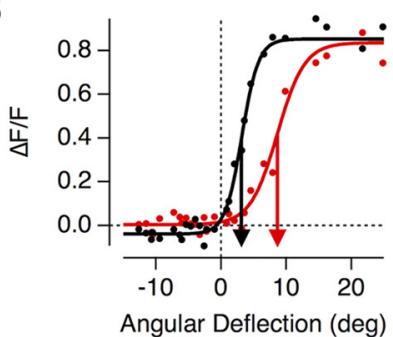

D

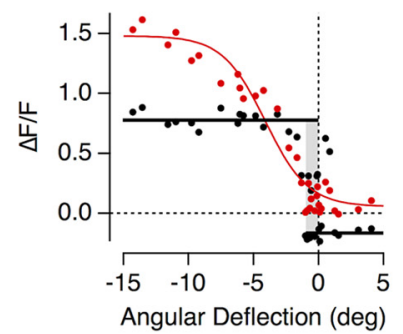

$\mathbf{F}$
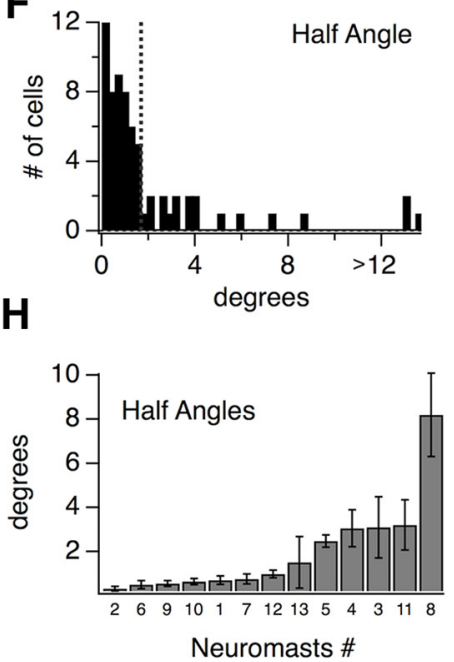

Figure 3. The transfer characteristics of hair cells in the lateral line. $\boldsymbol{A}$, iGluSnFR responses of two hair cells recorded in the same neuromast, both responding to positive pressure steps. The top one (black) responds to smaller deflections than the bottom one (red). The relationship between cupula deflection and applied pressure in this neuromast was $0.6 \mathrm{deg} / \mathrm{mmHg}$. $\boldsymbol{B}$, Peak iGluSnFR signals $(R)$ from $\boldsymbol{A}$ plotted as a function of the angular deflection of the cupula $(X)$. These stimulusresponse relations could be described by a two-state Boltzmann function (Eq. 3), with parameters $R_{\max }, R_{\min }, X_{1 / 2}$, and $X_{s}$ : $R_{\max (1)}=0.89 \pm 0.02, R_{\min (1)}=-0.04 \pm 0.01, X_{1 / 2(1)}=3.19 \pm 0.15^{\circ}$, and $X_{s(1)}=1.28 \pm 0.15, R_{\max (2)}=0.83 \pm 0.02$, $R_{\min (2)}=0.00 \pm 0.01, X_{1 / 2(2)}=8.65 \pm 0.34^{\circ}$, and $X_{s(2)}=2.07 \pm 0.3$. C, iGluSnFR responses of two hair cells from another neuromast, which differ more significantly in their WR. $\boldsymbol{D}$, Stimulus-response relations of the hair cell in $\boldsymbol{C}$. The hair cell depicted in red had a WR of $7^{\circ}$, and the one in black $\angle 1^{\circ}$ (gray bar). $\boldsymbol{C}, \boldsymbol{D}$, The relationship between applied pressure and measured cupula deflection in this neuromast was $1.9 \mathrm{deg} / \mathrm{mmHg}$. $\boldsymbol{E}$, A histogram of WRs (the deflection required to increase the response from 10 to $90 \%$ of maximum) measured in 67 hair cells. Approximately $30 \%$ have WRs within $1.5^{\circ}$. The last bin contains all hair cells $>12^{\circ} . F$, Histogram of the half angles $\left(X_{1 / 2}\right.$, the rotation at half maximum response) in 67 hair cells. The majority (75\%) had $X_{1 / 2}<2^{\circ}$ (dashed line). $\mathbf{G}, \boldsymbol{H}$, The average WRs and half-angles of hair cells from 13 different neuromasts, ranked in order. The neuromast number is indicated below each bar. No correlation between these metrics could be detected using a Spearman rank correlation test (error bars indicate SEM).

reaching an initial peak 100-150 ms from the onset of the command signal, as shown in Figure 1, $G$ and $H$. These kinetics are not limited by the reporter itself: glutamate released from a single vesicle generates an iGluSnFR signal that peaks within 5-10 ms (Marvin et al., 2013; Helassa et al., 2018; Lagnado et al., 2018). The off-rate of the iGluSnFR variant we used is also relatively fast, the transient generated by a single vesicle decaying with a timeconstant of 15-50 ms. The decline in iGluSnFR signals at the end of a pressure step was significantly slower (Fig. $1 G, H$ ), indicating that it was rate-limited by factors such as the cessation of glutamate release or the clearance of the transmitter rather than by dissociation of glutamate from iGluSnFR. The ability to resolve changes in synaptic glutamate concentration was therefore limited by the sampling frequency in our experiments rather than the kinetics of the sensor (Materials and Methods).

\section{Ribbon synapses in the lateral line can} signal deflections $<100 \mathrm{~nm}$

What is the mechanical sensitivity of hair cells in the lateral line? Relating spikes in the afferent nerve to estimates of cupula deflection, Haehnel-Taguchi et al. (2014) report that deflections $<8 \mu \mathrm{m}$ cannot be encoded. In contrast, calcium imaging in the hair cells themselves indicate that calcium responses can be elicited by deflections between $\sim 1$ and $3 \mu \mathrm{m}$ (Kindt et al., 2012; Sheets et al., 2012; Zhang et al., 2016). It is less clear how these calcium signals engage the exocytotic machinery and a recent report suggests that the efficiency with which calcium triggers release might vary between different ribbon synapses in the lateral line (Olt et al., 2014). Imaging glutamate release using iGluSnFR provided a more direct assay of the final output of hair cells in the lateral line.

An experiment measuring the input/ output relation of two nearby hair cells is shown in Figure 3A: iGluSnFR signals were measured in response to positive and negative pressure steps of increasing amplitude, each lasting $1 \mathrm{~s}$. It can be immediately seen that hair cell 1 (black trace) was more sensitive to small deflections from rest, generating changes in glutamate release at stimulus strengths that did not elicit glutamate release from hair cell 2 (red trace). The mechanical tuning of these receptors was characterized as the peak amplitude of the iGluSnFR signal (R) as a function of angular rotation of the cupula (X), as plotted in Figure 3B. A good empirical description of this relation was provided by a Boltzmann equation of the form:

$\mathrm{R}=\mathrm{R}_{\min }+\mathrm{R}_{\max } /\{1+\exp$

$$
\left.\left[\left(\mathrm{X}_{1 / 2}-\mathrm{X}\right) / \mathrm{X}_{\mathrm{s}}\right]\right\} \text {, }
$$

where $R_{\max }$ is the saturating response in the preferred direction, $R_{\min }$ is the maximum change in the null direction, $X_{1 / 2}$ is the rotation that half-activates (half angle), and $X_{\mathrm{S}}$ is the slope factor.

The sensitivity of a sensory system can be quantified as the change in response per unit change in stimulus (Dayan and Abbott, 2001; Butts and Goldman, 2006). In Equation 3, $X_{1 / 2}$ is the point at which the gradient of the function is steepest, and therefore defines the deflection at which the sensitivity of the hair cell 
is at its maximum (Dayan and Abbott, 2001; Butts and Goldman, 2006). The two synapses in Figure $3 B$ differed significantly in $X_{1 / 2}$ (arrowed) and a survey of half-angles across 67 hair cells from a total of 13 neuromasts is shown by the histogram in Figure $3 F$. Approximately $70 \%$ of synapses displayed half-angles $<2^{\circ}$; assuming that hair bundles move in tandem with the cupula, this corresponds to deflections $<170 \mathrm{~nm}$ at the top of the hair bundle $\sim 5 \mu \mathrm{m}$ tall (McHenry et al., 2008; Maeda et al., 2017). We conclude that the majority of hair cells in the lateral line have a mechanical sensitivity comparable to auditory hair cells in mice and other species (for review, see Fettiplace and Kim, 2014).

The variability in the average WR and half-angle measured within individual neuromasts is shown in Figure 3, $G$ and $H$. Between 2 and 10 hair cells were sampled in each (average 5), which constitutes $10-$ $50 \%$ of the total. There was no significant correlation between the average WR of the hair cells sampled within a neuromast and their average half-angle (Spearman rank correlation test). The variability in the averaged properties is likely to reflect the functionally heterogeneous populations of hair cells within each neuromast.

\section{Heterogeneous transfer characteristics of hair cells within individual neuromasts}

Hair cells within neuromasts also varied significantly in their WR- the deflection required to increase the response from $10 \%$ to 90\% of maximum (Markin and Hudspeth, 1995). The hair cells featured in Figure 3, $A$ and $B$, operated over relatively broad WRs of $490 \mathrm{~nm}\left(5.6^{\circ}\right)$ and $790 \mathrm{~nm}\left(9.0^{\circ}\right)$, respectively. Other hair cells, however, operated with much narrower WRs of $90 \mathrm{~nm}\left(\sim 1^{\circ}\right)$, as shown by the black trace in Figure $3 C$ and corresponding plot of the transfer function in Figure 3D. The coexistence of hair cells with significantly different transfer characteristics was again evident in this neuromast, where another cell signaled deflections with a WR of $630 \mathrm{~nm}$ (Fig. 3C, D, red traces).

The distribution of WRs across 67 hair cells from 13 neuromasts is shown by the histogram in Figure $3 E$, which displayed an initial peak followed by a long tail. The peak contained $\sim 60 \%$ of hair cells and was centered at $\sim 1.5^{\circ}$, which is equivalent to deflections of $130 \mathrm{~nm}$. These estimates fall within the range of measurements of the WR made in auditory and vestibular hair cells of a number of species (20-400 nm; Fettiplace and Kim, 2014). The other $40 \%$ of cells signaled much larger deflections, with WRs between $5^{\circ}$ and $30^{\circ}(0.5-2.5 \mu \mathrm{m})$.

Are these variations in the transfer characteristics of hair cells also evident in the activity of postsynaptic afferents? To investigate this question, imaged calcium signals in the afferents using GCaMP6f under the pan-neuronal $\mathrm{HuC}$ (elavl3) promoter (Fig. 4). These experiments revealed that the half-angles and WRs of afferent responses also varied significantly between different
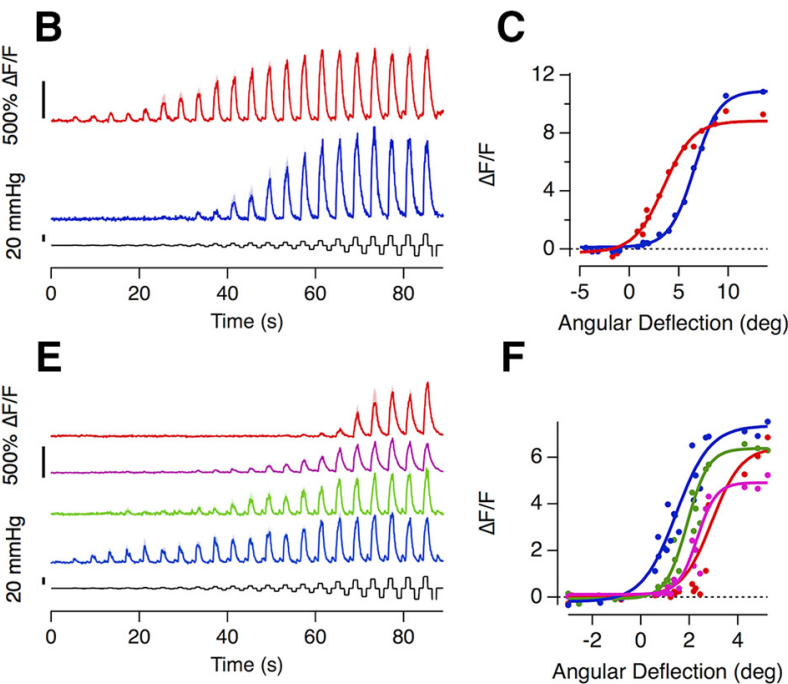

$\mathbf{F}$

H
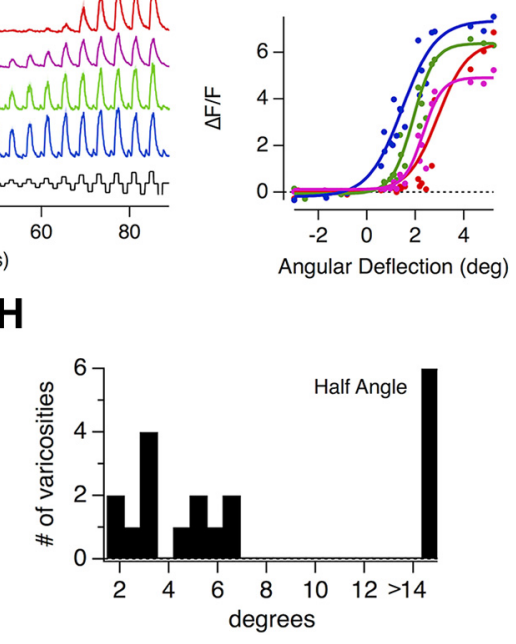

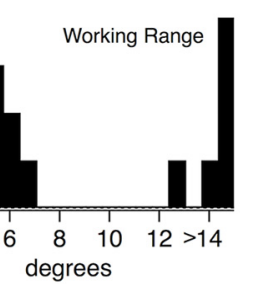

Figure 4. Heterogeneous transfer characteristics of hair cells revealed by measuring calcium signals in afferent neurons. $A, D$ . Neuromast 1 and $0.26 \mathrm{deg} / \mathrm{mmHg}$ in Neuromast 2. G, $\boldsymbol{H}$, The distribution of WRs and half-angles in 19 postsynaptic varicosities

synaptic contacts in the same neuromast (Fig. $4 A-F$ ), as well as in the population of neuromasts (Fig. $4 G, H$ ).

A number of processes between the mechanotransducer channel and the ribbon synapse might contribute to these variations in overall transfer characteristics of hair cells. For example, the input resistance of hair cells might vary such that a given MET current causes variable levels of depolarization; the voltage dependence of L-type calcium channels might alter depending on the action of neuromodulators, or the calcium dependence of the release process might change. Indeed, developmental heterogeneity of hair cells has been identified by measuring their electrophysiological properties (Olt et al., 2014) and calcium responses (Kindt et al., 2012). Furthermore, the existence of hair cells with different levels of functional maturity continues beyond the larval stage into the adult fish because hair cells undergo continuous turnover (Cruz et al., 2015). Whatever the underlying mechanisms, these results demonstrate that the neuromast encodes deflections of the cupula through a mixed population of receptors operating over different ranges. These heterogeneous transfer characteristics will likely determine the performance of the lateral line system in driving behaviors such as predator avoidance and rheotaxis as they are studied in these larval animals (Stewart et al., 2013; Oteiza et al., 2017).

\section{Individual hair cells can encode opposing directions of motion}

The two populations of hair cells polarized to opposite directions allow the neuromast to encode the direction of a stimulus using a 
A

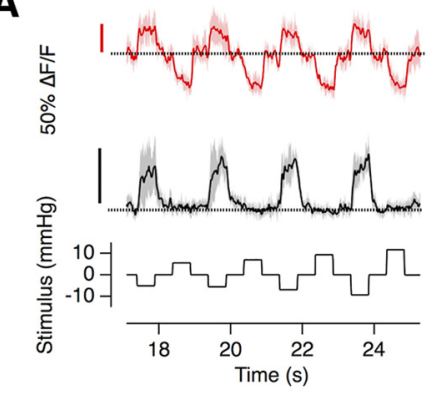

C

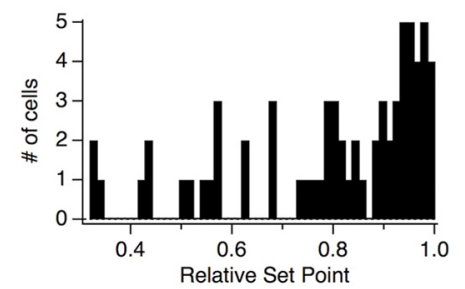

B

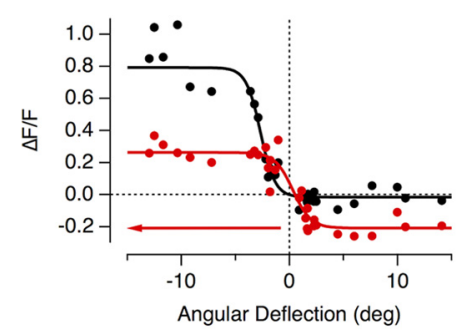

D

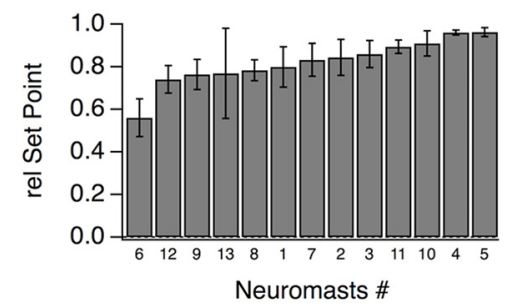

Figure 5. Push-pull signaling in individual hair cells. $\boldsymbol{A}$, The glutamate release from two hair cells in the same neuromast was measured using the iGluSnFR probe. Although both hair cells were polarized in the negative direction, the one depicted in black was completely rectifying but the hair cell in red could also clearly signal deflections in the positive direction as a decrease in glutamate release. The relationship between cupula deflection and applied pressure in this neuromast was $0.7 \mathrm{deg} / \mathrm{mmHg}$. $\boldsymbol{B}$, Stimulus-response relations of the hair cells $\operatorname{in} A . R_{\max (1)}=0.81 \pm 0.04, R_{\min (1)}=-0.02 \pm 0.07, X_{1 / 2(1)}=-2.68 \pm 0.18^{\circ}$, and $X_{s(1)}=0.67 \pm 0.16, R_{\max (2)}=0.47 \pm 0.03, R_{\min (2)}=-0.21 \pm 0.05, X_{1 / 2(2)}=0.32 \pm 0.36^{\circ}$, and $X_{s(2)}=0.83 \pm 0.22$. (Axis is reversed to represent the sensitivity to negative deflections.) The relative set-points of the black and red relations were 1 and 0.4 , respectively. C, Distribution of the relative set-points from 67 hair cells. Although the majority were strongly rectifying with relative set-points close to 1, there was a large degree of variability. $\boldsymbol{D}$, The average relative set-points of hair cells within the 13 neuromasts in increasing order.

push-pull system, similar in principle to the $\mathrm{ON}$ and OFF channels in the retina (Ghysen and Dambly-Chaudière, 2007; Masland, 2012). We found, however, that hair cells varied greatly in their ability to encode opposing directions of motion. For example, Figure $5 A$, red trace, shows a synapse where deflections of the cupula in the nonpreferred direction caused a large decrease in glutamate release: the input/output relation from this hair cell shows that $40 \%$ of its dynamic range was used to signal motion in the null direction (Fig. 5B). In contrast, another hair cell in the same neuromast was completely rectifying, only modulating release in the preferred direction (Fig. $5 A, B$, black trace).

The ability of individual hair cells to signal opposite directions of motion was quantified as the "relative set-point" for glutamate release- the fraction of the total dynamic range of the synapse modulated by deflections from rest in the preferred direction (Fettiplace and Kim, 2014). A synapse in which the maximum amplitude of the change in the iGluSnFR signal was equal for the positive and negative directions would, for instance, have a relative set-point of 0.5 (see Materials and Methods; Eq. 2). The distribution of relative set-points across a sample of 67 hair cells is shown by the histogram in Figure $5 C$. In $27 \%$ of synapses this fraction was $<0.7$, i.e., $>30 \%$ of the dynamic range was used to signal deflections in the null direction as a decrease in the rate of glutamate release. The variability in the relative set-point averaged within individual neuromasts is shown in Figure $5 D$. There was no significant correlation between this property and either the WR or half-angle measured within the 13 neuromasts (Spearman rank correlation test).

These results demonstrate that although the output from most hair cells in the posterior lateral line rectify strongly, the large majority can encode deflections of the cupula both toward and away from the head. This property will allow for larger dif- ferential signals in the two afferents, whereby an increase in the spike rate of one occurs simultaneously with a decrease in the rate of the second to below the spontaneous rate in the absence of a stimulus.

\section{A mixed population of high- and low- sensitivity hair cells}

How do hair cells with these different transfer characteristics act as a population to encode a deflection of the cupula? To obtain an overall picture of how the neuromast operates we estimated the total input to a single afferent by averaging the stimulus-response relation from 67 hair cells, assuming that hair cells of opposite polarity were, on average, mirror-images of each other (Fig. 6A). This assumption was based on the observation that the stimulus-response relations of hair cells signaling deflections toward the head were not significantly different from those signaling deflections toward the tail. The tuning curve averaged over all hair cells could be described as the sum of two sigmoid functions with significantly different slope factors and half-angles $\left(X_{\mathrm{S}(1)}=\right.$ $0.4 \pm 0.1, X_{\mathrm{S}(2)}=1.9 \pm 0.9, X_{1 / 2(1)}=$ $0.6 \pm 0.09^{\circ}$, and $\left.X_{1 / 2(2)}=6.1 \pm 1.1^{\circ}\right)$. The distribution of half-angles shown in Figure $3 F$ also indicated two basic populations of hair cells, separable either side of $X_{1 / 2}=2^{\circ}$, so we also calculated separate averages of the stimulus-response relations for hair cells above and below this threshold, as shown in Figure $6 B$. The slope factors and halfangles describing the transfer function of these two populations were $X_{\mathrm{S}\left(<2^{\circ}\right)}=0.5 \pm 0.04$ and $X_{1 / 2\left(<2^{\circ}\right)}=0.7 \pm 0.04$ (red trace), and $X_{\mathrm{S}\left(>2^{\circ}\right)}=1.8 \pm 0.3$ and $X_{1 / 2\left(>2^{\circ}\right)}=5.0 \pm 0$ (blue trace). Separating these populations according to $X_{1 / 2}$ revealed another important functional difference: hair cells of low sensitivity were completely rectifying with a relative set point of one while cells of high sensitivity had a relative set point of 0.8 .

The overall sensitivity of the neuromast was quantified as the first derivative of the stimulus-response relation (Dayan and Abbott, 2001). The thick dashed line in Figure $6 C$ shows this quantity for the average output of all 67 hair cells, from which three features stand out. First, the neuromast achieves maximum sensitivity at deflections of just $\sim 40 \mathrm{~nm}$ at the tip of the hair bundle. Second, deflections from rest can be signaled with a sensitivity $\sim 63 \%$ of maximum, either as an increase or a decrease in glutamate release, and this is made possible by the relative set-point of the high-sensitivity population of hair cells. Third, the high-sensitivity population saturates at deflection of $\sim 220 \mathrm{~nm}$, but the dynamic range of the neuromast as a whole is extended up to $\sim 1 \mu \mathrm{m}$ by the low-sensitivity population. Acting together, these two groups of hair cells make the neuromast very sensitive to small deflections of the cupula while maintaining a large dynamic range.

\section{Heterogeneous adaptive properties of hair cells within individual neuromasts}

The use of primary receptors of differing sensitivity is one strategy by which sensory systems maintain sensitivity over a range of stimulus strengths. A second strategy is to prevent saturation by 
A

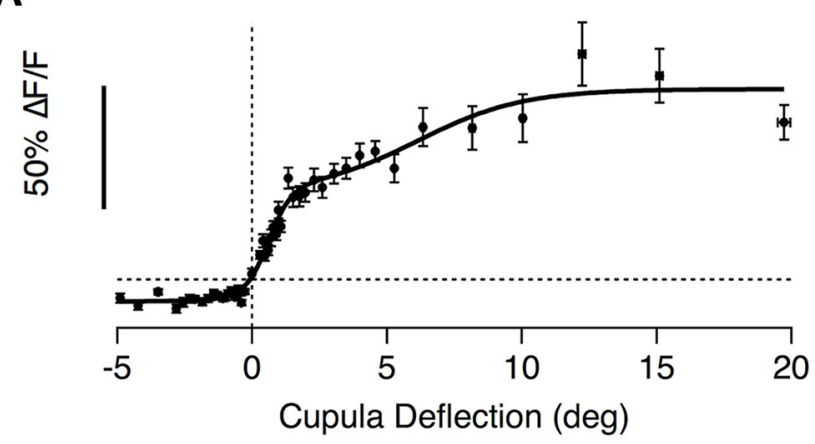

B

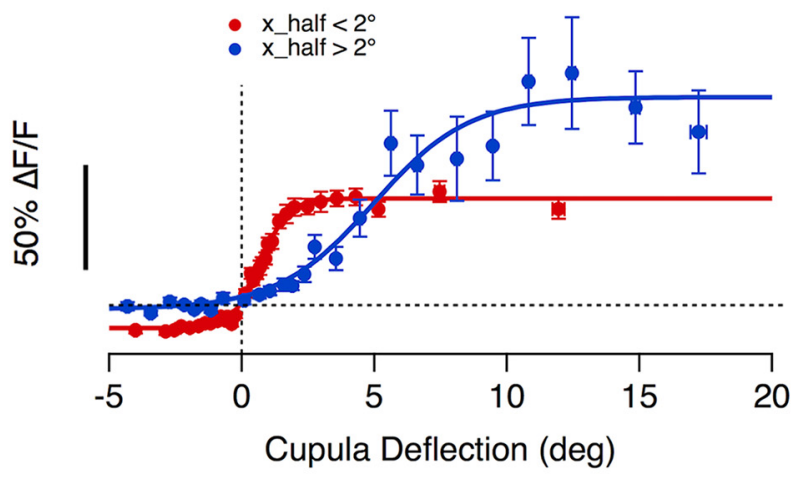

C

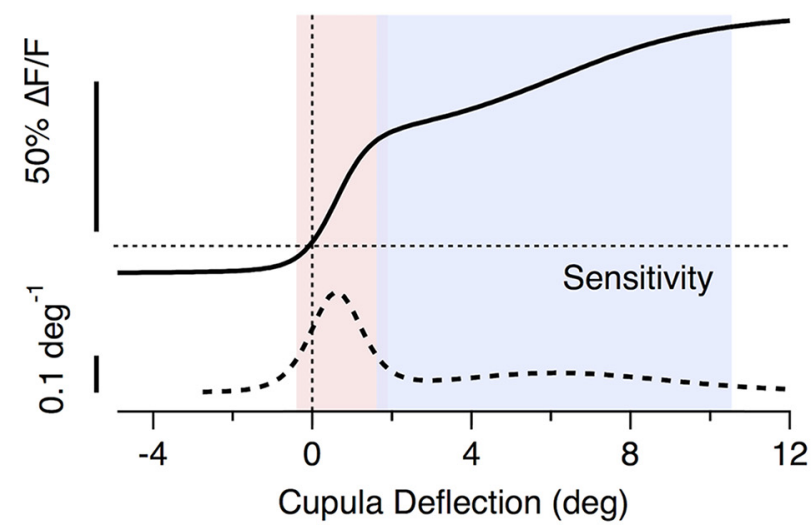

Figure 6. The average transfer characteristics of hair cells in a neuromast. $A$, The binned averages of 2800 individual paired measurements of cupula deflection and peak glutamate release, recorded from 67 hair cells using the iGluSnFR probe. All responses are plotted as a function of the magnitude of deflection, regardless of direction. A good empirical description was provided by the sum of two Boltzmann relations (Eq. 3 ) as shown by the fitted curve $\left(R_{\min }=0.1 \pm 0.02, R_{\max (1)}=0.44 \pm 0.09\right.$, $R_{\max (2)}=0.42 \pm 0.12, X_{1 / 2(1)}=0.60 \pm 0.1^{\circ}, X_{1 / 2(2)}=6.14 \pm 1.17^{\circ}, X_{s(1)}=0.42 \pm 0.12, X_{s(2)}=$ $1.95 \pm 0.95)$. The WR of the whole population is $8.9^{\circ}$. $\boldsymbol{B}$, The average stimulus-response relation of hair cells separated into two groups based on half-angle with a threshold of $2^{\circ}$. The two subsets had average half-angles of $0.7^{\circ}$ (red, $n=50$ hair cells) and $5^{\circ}$ (blue, $n=17$ hair cells). The high- and low-sensitvity groups of hair cells also differed significantly in $R_{\text {min, }}$, the maximum change in the null direction, with values of $-0.11 \pm 0.01$ and $-0.02 \pm 0.02$, respectively. The working rages of these populations were $2.3^{\circ}$ and $8^{\circ}$ respectively and overlapped between $1^{\circ}$ and $1.9^{\circ}$. C, The sensitivity of the whole population calculated as the derivative of the fit in $A$. Small deflections $\left(<2^{\circ}\right)$ are encoded with high sensitivity by the large population of hair cells whereas the second smaller population extends the dynamic range significantly to also capture larger cupula deflections, ranging beyond $10^{\circ}$.

adaptation, a change in sensitivity that often manifests itself as a time-dependent decrease in the response of a sensory neuron when a constant stimulus is applied (Adrian and Zotterman, 1926; Wark et al., 2007). In the lateral line, ramped deflections of the cupula cause the spike rates in the afferents to adapt strongly
(Haehnel-Taguchi et al., 2014) but it is unclear whether this is primarily a postsynaptic effect or whether there is also a presynaptic component to adaptation.

To investigate the adaptive properties of the neuromast we applied saturating or near-saturating pressure steps of $2 \mathrm{~s}$ or more. In 61 of 65 hair cells adaptation was apparent as synaptic depression but there was a large degree of variability within the same neuromast. For instance, Figure $7 A$ shows an example in which glutamate release fell to $\sim 30 \%$ of peak in one hair cell (red) but only to $70 \%$ of peak in another (black). We quantified the reduction in glutamate release as an $\mathrm{AI}$, which varied from 1 (complete recovery of the iGluSnFR signal to 0 ) through zero (no change) to negative values (reflecting an acceleration of glutamate release; detailed in Materials and Methods). The distribution of AIs measured at the end of a saturating $5 \mathrm{~s}$ pressure step varied widely, as shown by the distribution in Figure $7 \mathrm{C}$. The speed of decay of the response could be described by a timeconstant of 2 s or less in $74 \%$ of cells, and the distribution in this subpopulation is shown in Figure $7 D$. The remaining cells had a decay time-constant $>2$ s that could not be estimated reliably from a $5 \mathrm{~s}$ record. The shortest time constant we observed was $130 \mathrm{~ms}$ and $30 \%$ of all cells had a decay constant $<500 \mathrm{~ms}$.

Here we have used the term adaptation to mean the decline in the response to a maintained stimulus but it should be noted that this term is often used in a more specific way when characterizing the MET current providing the input to the hair cell. At this stage, adaptation can be measured as a change in the WR of the MET current that "resets" the deflection at which maximum sensitivity is achieved without significantly altering that maximum (Howard and Hudspeth, 1987; Shepherd and Corey, 1994; Holt et al., 2002; for review, see Ricci and Kachar, 2007).

These results demonstrate that hair cells of the lateral line apply different temporal filters: in some, a step stimulus generates a transient response that signals the onset of the deflection most strongly (Fig. 7A, red trace), whereas in others the output is more sustained and effectively signals the duration (Fig. $7 B$, black trace). An analogy can again be made with the transformation of signals in the retina, where the distinction between transient and sustained neurons has long been recognized (Baccus, 2007; Masland, 2012).

\section{Population signaling of a return to rest}

Here we have shown that push-pull signaling within a neuromast is facilitated by the high-sensitivity population of hair cells with relative set-points $<1$ (Figs. 5, 6B) and adaptation indices close to 1 (Fig. 7). Acting together, these features allow the neuromast to signal effectively the onset of a weak stimulus. A third and distinctive property of a subset of hair cells was the generation of a large glutamate transient at the offset of a stimulus. An example of this behavior is shown in Figure 8A: these two synapses were of opposite polarity and completely rectifying such that a deflection in the nonpreferred direction did not generate a response (green boxes). A return to rest from the nonpreferred direction did, however, generate a strong and transient release of glutamate (black boxes), equivalent to $88 \%$ of maximal response in the preferred direction. In other words, only one of the two hair cells signaled a deflection from rest, although both signaled a recovery to rest. To assess the numbers of hair cells generating such a reset or "rebound" signal we set a criterion that it must exceed $20 \%$ of the maximum response to a stimulus of the same magnitude in the preferred direction: 33 of 55 hair cells from 9 separate neuromasts generated such responses after steps of $1 \mathrm{~s}$ duration. Two observations ruled out the possibility that this signal was gener- 
A

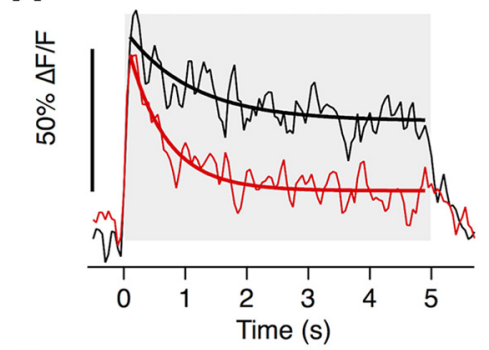

C

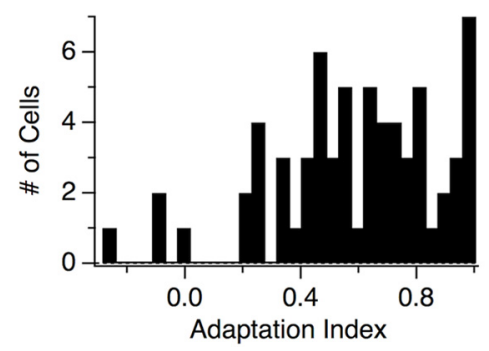

B

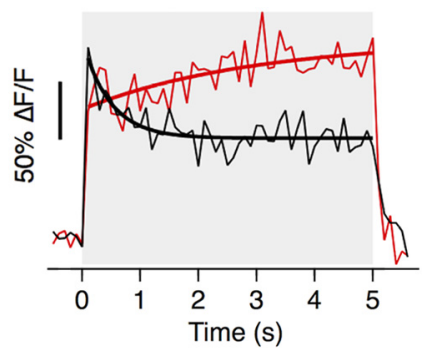

D

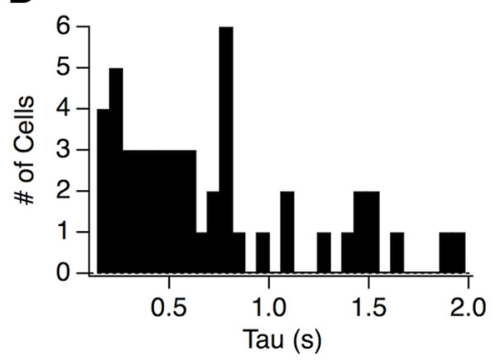

Figure 7. Heterogeneous adaptive properties of hair cells. $\boldsymbol{A}$, The glutamate release of two hair cells from the same neuromast adapts to different extents to a $5 \mathrm{~s}$ step deflection. The red one adapted with a time-constant of $0.61 \pm 0.09 \mathrm{~s}$ (solid line) with an adaptive index of 0.65 . The black hair cell adapted with a time-constant of $1.09 \pm 0.32 \mathrm{~s}$ with an adaptive index of 0.42 . $\boldsymbol{B}$, The iGluSnFR signal from two hair cells of a second neuromast. Note that while one adapted (black, $\mathrm{Al}=0.53$ ) the second sensitized $(A I=-0.13) . A, B$, Time-constants were derived from single exponential fits, thick lines). $\boldsymbol{C}$, Distribution of adaptation index from 65 hair cells stimulated with a 5 s step. D, Distribution of the decay time constants from the $55 \%$ of hair cells that could be fit with tau $<2 \mathrm{~s}$. In the remainder tau was $>2 \mathrm{~s}$ and could not be estimated.

ated by an overshoot or "swingback" of the cupula at the end of the step: such a swingback was not observed when imaging the cupula at $20 \mathrm{~Hz}$ (Fig. 2) and measurements within the same neuromast demonstrated that whereas some hair cells generated a reset response others did not (Fig. 8D).

The amplitude of the reset signal depended on both the magnitude and duration of the preceding deflection in the nonpreferred direction. The dependence on magnitude could be described by a two-state Boltzmann equation with a half-angle of $-0.6^{\circ}$ (50 nm; Fig. $8 \mathrm{~B}$ ) and during a large deflection the response developed with a time-constant of $0.3 \mathrm{~s}$ (Fig. $8 C$ ). The reset signals transmitted through the hair cell synapse are qualitatively similar to the process of "negative adaptation" described in the MET current of a variety of hair cells and might, therefore, be driven by these channels (Holt et al., 2002; Hirono et al., 2004; Stauffer et al., 2005; Hudspeth, 2014).

\section{Discussion}

Directly measuring the mechanical stimulus, deflection of the cupula, and the synaptic output, release of glutamate, has allowed us to specify the transfer characteristics of hair cells within neuromasts of the lateral line. We find that the input to this sensory system is determined by populations of hair cells with heterogeneous transfer characteristics (McHenry et al., 2009; Stewart et al., 2013; Olive et al., 2016; Oteiza et al., 2017). A comparison can be made with early visual processing, where the visual signal is decomposed through a variety of pathways or "channels" specialized to transmit different types of information, such as the ON and OFF channels signaling light increments or decrements, or the transient and sustained channels signaling fast or slow changes in light intensity (Baccus, 2007; Kastner and Baccus, 2011; Masland, 2012). Similarly, individual neuromasts can encode a mechanical stimulus through a number of functional channels varying in sensitivity, polarity, and temporal and adap- tive properties. Here we discuss how these variations contribute to the information that can be transmitted as well as the mechanisms by which they might arise.

\section{Sensitivity, WR, and set-point}

The high-sensitivity group of hair cells operated with half-angles $\sim 1.5^{\circ}$ (Fig. $3 F$ ), which corresponds to a displacement of $130 \mathrm{~nm}$ at the tip of the stereocilia and is comparable to the sensitivity of auditory and vestibular hair cells in mice and other species (Fettiplace and Kim, 2014). This subset of hair cells saturated at deflections of $\sim 220 \mathrm{~nm}$ (Fig. $6 B$ ), which is much narrower than the WR of the neuromast as a whole (HaehnelTaguchi et al., 2014). The difference can be accounted for by the second, lowsensitivity population of hair cells that extended the dynamic range of the neuromast beyond $1 \mu \mathrm{m}$. A strategy for detecting stimuli with a mixture of high- and low-sensitivity receptors allows the neuromast to encode weak stimuli effectively while limiting saturation.

An important feature of the highsensitivity hair cells was a relative setpoint that allowed small deflections in either direction to modulate glutamate release (Figs. 5, 6). The sensitivity to deflections from rest achieved $63 \%$ of the maximum measured at $\sim 40 \mathrm{~nm}$ (Fig. $6 \mathrm{C}$ ) so it seems likely that deflections $<50 \mathrm{~nm}$ will be transmitted to targets in the hindbrain. The behavioral significance of detecting such small deflections is, however, harder to judge and would require one to measure (or perhaps calculate) deflections of the cupula in a motile fish. One possibility is that the high-sensitivity group of hair cells are involved in the sensing of flow velocity gradients around the body of the fish that have recently been shown to underlie rheotaxis in the absence of visual input (Oteiza et al., 2017). Low-sensitivity hair cells would then be available to encode stronger stimuli triggering reflexes such as the escape response, a locomotor behavior that rapidly propels the fish away from a threat.

An important limitation of the current experiments was the sampling rate of iGluSnR signals. Imaging at $20 \mathrm{~Hz}$, we were effectively blind to events occurring within the first $50 \mathrm{~ms}$ of an applied stimulus. The displacement generated by intermediate pressure steps settled within 50 ms (Fig. 2 H,I) but ribbon synapses are capable of releasing vesicles within milliseconds of calcium current activation (Keen and Hudspeth, 2006; Li et al., 2009). It may therefore be that these experiments underestimate the peak sensitivity of hair cells assayed at their output. Improved estimates might be obtained by sampling both the iGluSnFR signal and cupula deflection at rates of $100 \mathrm{~Hz}$ or more, although this is unlikely to be worthwhile until the signal-to-noise ratio of these imaging methods are improved significantly.

\section{Possible mechanisms underlying variations in sensitivity and set-point}

The input/output relation of the hair cell is determined by a chain of events, several of which might be sources of variation. The first step to consider is the mechanical coupling between the cupula 
and the hair bundles embedded within it. It is not known whether the hair bundle is fixed within the cupula to follow it exactly or whether relative displacements might occur large enough to modulate glutamate release. If the set position of different hair bundles varies because of interactions with the cupula then the resting transducer current and the operating set-point could be different. Similarly, if the attachment points of the kinocilia within the cupula or the stereocilia to the cupula varied this would alter the mechanical stimulus applied to different hair bundles, which would manifest itself as variations in the sensitivity of different hair cells. Variations in the relationship between hair bundle displacement and the MET current have also been observed within a single experiment in the auditory and vestibular systems (Holt et al., 1997; Stauffer and Holt, 2007).

A change in sensitivity measured at the output might also reflect the process of $\mathrm{Ca}^{2+}$-triggered exocytosis at the active zone. It has been shown, for instance, that the amplitude of calcium signals varies between hair cells within a neuromast of the larval zebrafish, reflecting different levels of developmental maturity (Kindt et al., 2012, Olt et al., 2014). It may therefore be that the lesssensitive population of hair cells that we have identified by their transfer function is synonymous with hair cells that are functionally immature with smaller calcium currents. A heterogeneous population of hair cells at different levels of maturity is likely to continue into adulthood because hair cells in neuromasts turnover continuously as they are damaged and regenerate (Cruz et al., 2015). Even within a single hair cell active zones may vary in the number of calcium channels and their voltage dependence, leading to different release rates driven by the same receptor potential (Ohn et al., 2016). Finally, variations in sensitivity at the output might also reflect differences in the efficiency with which a given $\mathrm{Ca}^{2+}$ signal triggers exocytosis (Olt et al., 2014).

The set-point for signaling the output from a hair cell will depend on where the resting potential sits relative to the threshold for activation of calcium channels. Push-pull modulation of glutamate within individual hair cells requires that the resting potential be in a range where $\mathrm{Ca}_{\mathrm{V}} 1.3$ channels under the ribbon are activated sufficiently to drive vesicle fusion (Platzer et al., 2000; Olt et al., 2014). If the resting potential is hyperpolarized relative to the threshold the output of the hair cell will be completely rectifying, as observed in the lowsensitivity population of hair cells. Conductances that might cause resting potentials to vary include $\mathrm{K}^{+}$channels in the basolateral membrane (Olt et al., 2014) and $I_{\mathrm{h}}$ inward rectifiers (Trapani and Nicolson, 2011). The voltage dependence of
$\mathrm{Ca}_{\mathrm{V}} 1.3$ channels may also be subject to modulation that alters the threshold for activation and the steepness of the currentvoltage relation (Striessnig et al., 2010).

\section{Adaptation}

We also found large variations in the degree and speed of adaptation between different hair cells within a neuromast (Fig. 7). Such a mixture of responses will help the population within a neuromast to signal both sustained stimuli, such as water flow (Voigt et al., 2000), as well as sudden deviations, such as eddy currents or the motion of other creatures in their immediate environment (McHenry et al., 2009). There are likely to be a number of processes that contribute to adaptation in the synaptic output measured using iGluSnFR, beginning with, but not confined to, adaptation at the MET channel. In hair cells of the au- 
ditory and vestibular systems a second major cause of adaptation measured at the output is vesicle depletion leading to depression at the ribbon synapse (Schnee et al., 2005, 2011; Goutman, 2017). These two processes have been studied in isolation, but the present study has assessed how they act together to adjust the input/ output relation of the hair cell.

The kinetics of adaptation of the MET current can generally be described by two time constants, $\tau_{\text {fast }}$ in the milliseconds range and $\tau_{\text {slow }}$ in the tens of milliseconds range (Shepherd and Corey, 1994; Holt et al., 1997; Vollrath and Eatock, 2003; Stauffer and Holt, 2007). It is not, however, clear whether these processes are mirrored in the exocytic response of the hair cell. Ribbon synapses contain a pool of docked vesicles that can be released completely within $\sim 20 \mathrm{~ms}$ when the calcium current is activated strongly (Burrone and Lagnado, 2000; Beutner et al., 2001), but such a fast and transient response would not have been resolved in the present experiments. We were, however, able to resolve adaptation of the output that occurred on time-scales of hundreds of milliseconds to seconds (Fig. 7). These relatively slow kinetics indicate that the rate-limiting process was downstream of the MET channel and a strong possibility is that adaptation reflected depletion of releasable vesicles at the active zone. Indeed, capacitance measurements of exocytosis in hair cells of the lateral line demonstrate that a strong step depolarization stimulates release that decays with time constants of $\sim 500 \mathrm{~ms}$ (Eatock, 2000; Lv et al., 2016), whereas optical measurements at ribbon synapses in the retina demonstrate that these can also depress with time-constants of a few seconds (Nikolaev et al., 2013).

A related property was so-called negative adaptation, whereby deflections of the hair bundle away from the kinocilium primed the hair cell to generate a transient burst of glutamate release when the cupula returned toward rest (Fig. 8 ). This response signaled the offset of a stimulus and was a function of both the amplitude and duration of the preceding deflection, thereby encoding the integrated stimulus. Negative adaptation within the neuromast generates a population signal that encodes the cessation of a stimulus, as would occur, for instance, in the intervals between swimming bouts (Russell and Roberts, 1974; Palmer et al., 2005). The growth of the reset signal with time and angle of deflection indicate that it has the potential to be used to integrate flow gradients along the body of the side of the fish, the detection of which underlies rheotaxis (Oteiza et al., 2017).

\section{References}

Adrian ED, Zotterman Y (1926) The impulses produced by sensory nerveendings. Part II: The response of a single end-organ. J Physiol 61:151-171. CrossRef Medline

Baccus SA (2007) Timing and computation in inner retinal circuitry. Annu Rev Physiol 69:271-290. CrossRef Medline

Beutner D, Voets T, Neher E, Moser T (2001) Calcium dependence of exocytosis and endocytosis at the cochlear inner hair cell afferent synapse. Neuron 29:681-690. CrossRef Medline

Borghuis BG, Marvin JS, Looger LL, Demb JB (2013) Two-photon imaging of nonlinear glutamate release dynamics at bipolar cell synapses in the mouse retina. J Neurosci 33:10972-10985. CrossRef Medline

Brandt A, Khimich D, Moser T (2005) Few CaV1.3 channels regulate the exocytosis of a synaptic vesicle at the hair cell ribbon synapse. J Neurosci 25:11577-11585. CrossRef Medline

Brand M, Granato M, Nüsslein-Volhard C (2002) Keeping and raising zebrafish. In: Zebrafish: a practical approach, pp 7-37. Oxford, UK: Oxford UP.

Burrone J, Lagnado L (2000) Synaptic depression and the kinetics of exocytosis in retinal bipolar cells. J Neurosci 20:568-578. CrossRef Medline
Butts DA, Goldman MS (2006) Tuning curves, neuronal variability, and sensory coding. PLoS Biol. 4:e92. CrossRef Medline

Chou SW, Chen Z, Zhu S, Davis RW, Hu J, Liu L, Fernando CA, Kindig K, Brown WC, Stepanyan R, McDermott BM Jr (2017) A molecular basis for water motion detection by the mechanosensory lateral line of zebrafish. Nat Commun 8:2234. CrossRef Medline

Cruz IA, Kappedal R, Mackenzie SM, Hailey DW, Hoffman TL, Schilling TF, Raible DW (2015) Robust regeneration of adult zebrafish lateral line hair cells reflects continued precursor pool maintenance. Dev Biol 402: 229-238. CrossRef Medline

Dayan P, Abbott LF (2001) Theoretical neuroscience. Cambridge, MA: MIT.

Dorostkar MM, Dreosti E, Odermatt B, Lagnado L (2010) Computational processing of optical measurements of neuronal and synaptic activity in networks. J Neurosci Methods 188:141-150. CrossRef Medline

Eatock RA (2000) Adaptation in hair cells. Annu Rev Neurosci 23:285-314. CrossRef Medline

Erickson T, Morgan CP, Olt J, Hardy K, Busch-Nentwich E, Maeda R, Clemens R, Krey JF, Nechiporuk A, Barr-Gillespie PG, Marcotti W, Nicolson T (2017) Integration of Tmc1/2 into the mechanotransduction complex in zebrafish hair cells is regulated by transmembrane $O$-methyltransferase (Tomt). eLife 6:e28474. CrossRef Medline

Faucherre A, Pujol-Martí J, Kawakami K, López-Schier H (2009) Afferent neurons of the zebrafish lateral line are strict selectors of hair-cell orientation. PloS One. 4:e4477. CrossRef Medline

Fettiplace R, Kim KX (2014) The physiology of mechanoelectrical transduction channels in hearing. Physiol Rev 94:951-986. CrossRef Medline

Ghysen A, Dambly-Chaudière C (2007) The lateral line microcosmos. Genes Dev 21:2118-2130. CrossRef Medline

Goutman JD (2017) Mechanisms of synaptic depression at the hair cell ribbon synapse that support auditory nerve function. Proc Natl Acad Sci U S A 114:9719-9724. CrossRef Medline

Granseth B, Odermatt B, Royle SJ, Lagnado L (2006) Clathrin-mediated endocytosis is the dominant mechanism of vesicle retrieval at hippocampal synapses. Neuron 51:773-786. CrossRef Medline

Graydon CW, Manor U, Kindt KS (2017) In vivo ribbon mobility and turnover of ribeye at zebrafish hair cell synapses. Sci Rep 7:7467. CrossRef Medline

Haehnel-Taguchi M, Akanyeti O, Liao JC (2014) Afferent and motoneuron activity in response to single neuromast stimulation in the posterior lateral line of larval zebrafish. J Neurophysiol 112:1329-1339. CrossRef Medline

Helassa N, Dürst CD, Coates C, Kerruth S, Arif U, Schulze C, Wiegert JS, Geeves M, Oertner TG, Török K (2018) Ultrafast glutamate sensors resolve high-frequency release at Schaffer collateral synapses. Proc Natl Acad Sci U S A 115:5594-5599. CrossRef Medline

Hirono M, Denis CS, Richardson GP, Gillespie PG (2004) Hair cells require phosphatidylinositol 4,5-bisphosphate for mechanical transduction and adaptation. Neuron 44:309-320. CrossRef Medline

Holt JR, Corey DP, Eatock RA (1997) Mechanoelectrical transduction and adaptation in hair cells of the mouse utricle, a low-frequency vestibular organ. J Neurosci 17:8739-8748. CrossRef Medline

Holt JR, Gillespie SK, Provance DW, Shah K, Shokat KM, Corey DP, Mercer JA, Gillespie PG (2002) A chemical-genetic strategy implicates myosin-1c in adaptation by hair cells. Cell 108:371-381. CrossRef Medline

Howard J, Hudspeth AJ (1987) Mechanical relaxation of the hair bundle mediates adaptation in mechanoelectrical transduction by the bullfrog's saccular hair cell. Proc Natl Acad Sci U S A 84:3064-3068. CrossRef Medline

Hudspeth AJ (2014) Integrating the active process of hair cells with cochlear function. Nat Rev Neurosci 15:600-614. CrossRef Medline

Kastner DB, Baccus SA (2011) Coordinated dynamic encoding in the retina using opposing forms of plasticity. Nat Neurosci 14:1317-1322. CrossRef Medline

Keen EC, Hudspeth AJ (2006) Transfer characteristics of the hair cell's afferent synapse. Proc Natl Acad Sci U S A 103:5537-5542. CrossRef Medline

Kindt KS, Finch G, Nicolson T (2012) Kinocilia mediate mechanosensitivity in developing zebrafish hair cells. Dev Cell 23:329-341. CrossRef Medline

Lagnado L, James B, Darnet L, Moya-Diaz J, Seibel SH (2018) An amplitude code increases the efficiency of information transmission across a visual synapse. bioRxiv. CrossRef 
Li GL, Keen E, Andor-Ardó D, Hudspeth AJ, von Gersdorff H (2009) The unitary event underlying multiquantal EPSCs at a hair cell's ribbon synapse. J Neurosci 29:7558-7568. CrossRef Medline

Lister JA, Robertson CP, Lepage T, Johnson SL, Raible DW (1999) nacre encodes a zebrafish microphthalmia-related protein that regulates neuralcrest-derived pigment cell fate. Development 126:3757-3767. Medline

Lv C, Stewart WJ, Akanyeti O, Frederick C, Zhu J, Santos-Sacchi J, Sheets L, Liao JC, Zenisek D (2016) Synaptic ribbons require ribeye for electron density, proper synaptic localization, and recruitment of calcium channels. Cell Rep 15:2784-2795. CrossRef Medline

Maeda R, Pacentine IV, Erickson T, Nicolson T (2017) Functional analysis of the transmembrane and cytoplasmic domains of Pcdh15a in zebrafish hair cells. J Neurosci 37:3231-3245. CrossRef Medline

Markin VS, Hudspeth AJ (1995) Gating-spring models of mechanoelectrical transduction by hair cells of the internal ear. Annu Rev Biophys Biomol Struct 24:59-83. CrossRef Medline

Marvin JS, Borghuis BG, Tian L, Cichon J, Harnett MT, Akerboom J, Gordus A, Renninger SL, Chen TW, Bargmann CI, Orger MB, Schreiter ER, Demb JB, Gan WB, Hires SA, Looger LL (2013) An optimized fluorescent probe for visualizing glutamate neurotransmission. Nat Methods 10:162-170. CrossRef Medline

Masland RH (2012) The neuronal organization of the retina. Neuron 76: 266-280. CrossRef Medline

McHenry MJ, van Netten SM (2007) The flexural stiffness of superficial neuromasts in the zebrafish (Danio rerio) lateral line. J Exp Biol 210: 4244-4253. CrossRef Medline

McHenry MJ, Strother JA, van Netten SM (2008) Mechanical filtering by the boundary layer and fluid-structure interaction in the superficial neuromast of the fish lateral line system. J Comp Physiol A Neuroethol Sens Neural Behav Physiol 194:795-810. CrossRef Medline

McHenry MJ, Feitl KE, Strother JA, Van Trump WJ (2009) Larval zebrafish rapidly sense the water flow of a predator's strike. Biol Lett 5:477-479. CrossRef Medline

Nicolson T (2015) Ribbon synapses in zebrafish hair cells. Hear Res 330: 170-177. CrossRef Medline

Nikolaev A, Leung KM, Odermatt B, Lagnado L (2013) Synaptic mechanisms of adaptation and sensitization in the retina. Nat Neurosci 16:934941. CrossRef Medline

Odermatt B, Nikolaev A, Lagnado L (2012) Encoding of luminance and contrast by linear and nonlinear synapses in the retina. Neuron 73:758773. CrossRef Medline

Ohn TL, Rutherford MA, Jing Z, Jung S, Duque-Afonso CJ, Hoch G, Picher MM, Scharinger A, Strenzke N, Moser T (2016) Hair cells use active zones with different voltage dependence of $\mathrm{Ca}^{2+}$ influx to decompose sounds into complementary neural codes. Proc Natl Acad Sci U S A 113: E4716-4725. CrossRef Medline

Olive R, Wolf S, Dubreuil A, Bormuth V, Debrégeas G, Candelier R (2016) Rheotaxis of larval zebrafish: behavioral study of a multi-sensory process. Front Syst Neurosci 10:14. CrossRef Medline

Olt J, Johnson SL, Marcotti W (2014) In vivo and in vitro biophysical properties of hair cells from the lateral line and inner ear of developing and adult zebrafish. J Physiol 592:2041-2058. CrossRef Medline

Oteiza P, Odstrcil I, Lauder G, Portugues R, Engert F (2017) A novel mechanism for mechanosensory-based rheotaxis in larval zebrafish. Nature 547:445-448. CrossRef Medline

Palmer LM, Deffenbaugh M, Mensinger AF (2005) Sensitivity of the anterior lateral line to natural stimuli in the oyster toadfish, Opsanus tau (Linnaeus). J Exp Biol 208:3441-3450. CrossRef Medline

Platzer J, Engel J, Schrott-Fischer A, Stephan K, Bova S, Chen H, Zheng H, Striessnig J (2000) Congenital deafness and sinoatrial node dysfunction in mice lacking class D L-type $\mathrm{Ca}^{2+}$ channels. Cell 102:89-97. CrossRef Medline

Pujol-Martí J, Zecca A, Baudoin JP, Faucherre A, Asakawa K, Kawakami K,
López-Schier H (2012) Neuronal birth order identifies a dimorphic sensorineural map. J Neurosci 32:2976-2987. CrossRef Medline

Pujol-Martí J, López-Schier H (2013) Developmental and architectural principles of the lateral-line neural map. Front Neural Circuits 7:47. CrossRef Medline

Ricci AJ, Bai JP, Song L, Lv C, Zenisek D, Santos-Sacchi J (2013) Patchclamp recordings from lateral line neuromast hair cells of the living zebrafish. J Neurosci 33:3131-3134. CrossRef Medline

Ricci AJ, Kachar B (2007) Hair cell mechanotransduction: the dynamic interplay between structure and function. Curr Top Membr 59:339-374. CrossRef Medline

Russell IJ, Roberts BL (1974) Active reduction of lateral-line sensitivity in swimming dogfish. J Comp Physiol 94:7-15. CrossRef

Schnee ME, Lawton DM, Furness DN, Benke TA, Ricci AJ (2005) Auditory hair cell-afferent fiber synapses are specialized to operate at their best frequencies. Neuron 47:243-254. CrossRef Medline

Schnee ME, Santos-Sacchi J, Castellano-Muñoz M, Kong JH, Ricci AJ (2011) Calcium-dependent synaptic vesicle trafficking underlies indefatigable release at the hair cell afferent fiber synapse. Neuron 70:326-338. CrossRef Medline

Sheets L, Kindt KS, Nicolson T (2012) Presynaptic CaV1.3 channels regulate synaptic ribbon size and are required for synaptic maintenance in sensory hair cells. J Neurosci 32:17273-17286. CrossRef Medline

Sheets L, He XJ, Olt J, Schreck M, Petralia RS, Wang YX, Zhang Q, Beirl A, Nicolson T, Marcotti W, Trapani JG, Kindt KS (2017) Enlargement of ribbons in zebrafish hair cells increases calcium currents but disrupts afferent spontaneous activity and timing of stimulus onset,. J Neurosci 37:6299-6313. CrossRef Medline

Shepherd GM, Corey DP (1994) The extent of adaptation in bullfrog saccular hair cells. J Neurosci 14:6217-6229. CrossRef Medline

Stauffer EA, Holt JR (2007) Sensory transduction and adaptation in inner and outer hair cells of the mouse auditory system. J Neurophysiol 98: 3360-3369. CrossRef Medline

Stauffer EA, Scarborough JD, Hirono M, Miller ED, Shah K, Mercer JA, Holt JR, Gillespie PG (2005) Fast adaptation in vestibular hair cells requires myosin-1c activity. Neuron 47:541-553. CrossRef Medline

Stewart WJ, Cardenas GS, McHenry MJ (2013) Zebrafish larvae evade predators by sensing water flow. J Exp Biol 216:388-398. CrossRef Medline

Striessnig J, Bolz HJ, Koschak A (2010) Channelopathies in Cav1.1, Cav1.3, and Cav1.4 voltage-gated L-type $\mathrm{Ca}^{2+}$ channels. Pflügers Archiv: Eur J Physiol 460:361-374. CrossRef

Trapani JG, Nicolson T (2011) Mechanism of spontaneous activity in afferent neurons of the zebrafish lateral-line organ. J Neurosci 31:1614-1623. CrossRef Medline

Trapani JG, Obholzer N, Mo W, Brockerhoff SE, Nicolson T (2009) Synaptojanin1 is required for temporal fidelity of synaptic transmission in hair cells. PLoS Genet 5:e1000480. CrossRef Medline

Voigt R, Carton AG, Montgomery JC (2000) Responses of anterior lateral line afferent neurones to water flow. J Exp Biol 203:2495-2502. Medline

Vollrath MA, Eatock RA (2003) Time course and extent of mechanotransducer adaptation in mouse utricular hair cells: comparison with frog saccular hair cells. J Neurophysiol 90:2676-2689. CrossRef Medline

Wark B, Lundstrom BN, Fairhall A (2007) Sensory adaptation. Curr Opin Neurobiol 17:423-429. CrossRef Medline

Weisz CJ, Lehar M, Hiel H, Glowatzki E, Fuchs PA (2012) Synaptic transfer from outer hair cells to type II afferent fibers in the rat cochlea. J Neurosci 32:9528-9536. CrossRef Medline

Zhang QX, He XJ, Wong HC, Kindt KS (2016) Functional calcium imaging in zebrafish lateral-line hair cells. Methods Cell Biol 133:229-252. CrossRef Medline

Zhang Q, Li S, Wong HC, He XJ, Beirl A, Petralia RS, Wang YX, Kindt KS (2018) Synaptically silent sensory hair cells in zebrafish are recruited after damage. Nat Commun 9:1388. CrossRef Medline 